\title{
Combination Therapy for Renal Cell Cancer: What Are Possible Options?
}

\author{
Napoleon Santos $^{a}$ Justin B. Wenger ${ }^{a}$ Pamela Havre $^{a}$ Yanxia Liu ${ }^{c}$ Roi Dagan ${ }^{b}$ \\ Iman Imanirad $^{a} \quad$ Alison M. Ivey $^{a}$ Robert A. Zlotecki ${ }^{b}$ Chester B. Algood ${ }^{d}$ \\ Scott M. Gilbert ${ }^{d}$ Carmen J. Allegra ${ }^{a}$ Paul Okunieff ${ }^{b}$ Johannes Vieweg ${ }^{d}$ \\ Nam H. Dang a Hendrik Luesch ${ }^{c}$ Long H. Dang ${ }^{a}$ \\ a Division of Hematology/Oncology, Department of Internal Medicine, and ${ }^{b}$ Department of Radiation Oncology, \\ University of Florida Shands Cancer Center, University of Florida, and Departments of ${ }^{\mathrm{C}}$ Medicinal Chemistry and \\ dUrology, University of Florida, Gainesville, Fla., USA
}

\section{Key Words}

Hypoxia-inducible factor- $1 \alpha \cdot$ Hypoxia-inducible factor- $2 \alpha \cdot$ Antiangiogenic therapy $\cdot$ Renal cell cancer $\cdot$ Multikinase inhibitor $\cdot \mathrm{mTOR}$

\begin{abstract}
Antiangiogenic therapy has shown promise in the treatment of patients with renal cell carcinoma (RCC). Two classes of antiangiogenic drugs, the anti-vascular endothelial growth factor antibody bevacizumab and the tyrosine kinase inhibitors sorafenib, sunitinib and pazopanib, have shown efficacy in patients with RCC and are approved by the US Food and Drug Administration for treatment of this cancer. In practice, the clinical benefit of antiangiogenic drugs in RCC has been heterogeneous, and in patients who do respond, benefits are modest and/or short-lived. To improve efficacy, combination targeted therapy has been attempted, but with either very limited additional efficacy or nontolerable toxicities. Recent advances in the molecular understanding of tumor angiogenesis and mechanism of resistance, along with the rapid development of targeted drug discovery, have made it possible to further explore novel combination therapy for RCC.

Copyright $\odot 2011$ S. Karger AG, Basel
\end{abstract}

\section{Introduction}

It is estimated that close to 61,000 new cases of kidney and renal pelvis cancer will be diagnosed in the USA in 2011, and 13,000 patients will succumb to the disease [1]. Their incidence has risen by $2-3 \%$ every year since the early 1990s, many cases being discovered serendipitously due to the increased use of CT scans. Of the renal malignancies, $92 \%$ are renal cell carcinoma (RCC). Renal carcinomas, which are adenocarcinomas of the renal tubular epithelium, can be further distinguished into clear cell carcinoma (accounting for $70-80 \%$ of all RCCs), papillary carcinoma (10-15\%), chromophobe renal carcinoma and collecting duct carcinoma (6\% or less, collectively) [2]. Surgery (radical or partial nephrectomy) remains the mainstay of treatment for RCC. Unfortunately, about one third of patients who undergo surgical resection for localized disease have recurrence [1]. Prior to 2005, patients with locally invasive or metastatic disease received immunomodulatory therapy with modest survival benefit, at the expense of considerable toxicity. Since then, six targeted agents, bevacizumab, sorafenib, sunitinib, pazopanib, temsirolimus and everolimus, have been approved by the US Food and Drug Administration (FDA) for the treat-

\section{KARGER}

두 2011 S. Karger AG, Basel

Fax +41613061234

E-Mail karger@karger.ch

www.karger.com

\footnotetext{
Long H. Dang

PO Box 100278

Gainesville, FL 32610-0278 (USA)

Tel. +1 3522737832
}

E-Mail long.dang@medicine.ufl.edu 
ment of advanced RCC. In general, these agents have higher efficacy against clear cell than non-clear cell histologies.

Antiangiogenic therapy has shown promise in the treatment of patients with metastatic RCC (mRCC). This novel class of drugs was designed to inhibit the vascular endothelial growth factor (VEGF) pathway, as VEGF is the most prevalent and dominant proangiogenic growth factor in the tumor microenvironment [3-6]. FDA-approved agents that directly target the VEGF pathway include the anti-VEGF antibody bevacizumab and the multitargeted tyrosine kinase inhibitors (TKIs) sunitinib, sorafenib and pazopanib, which inhibit VEGF receptors along with other receptor tyrosine kinases [7-12]. Although these drugs have shown improvement in overall survival (OS) in advanced RCC, durable responses are rare, and resistance to treatment is usually seen after a median of 6-15 months [5]. Therefore, novel approaches are desperately needed.

We review clinical trial results, discuss the mechanism of resistance to antiangiogenic therapy and suggest novel combinations with antiangiogenic drugs for the treatment of advanced RCC or mRCC.

\section{Current Evidence of Combination Targeted Therapy in Advanced RCC}

Bevacizumab has been extensively tested in combination with a myriad of targeted and nontargeted therapies for the treatment of mRCC; however, despite a number of important victories, successful treatment using this agent as part of a combination regimen has been largely underwhelming. It was first found to have significant clinical benefit by Yang et al. [13] when used as monotherapy. Until the advent of targeted therapy for RCC within the last decade, interferon- $\alpha$ (IFN- $\alpha$ ) was one of the few options for treatment of patients with advanced RCC. However, its efficacy was marginal at best and its effects usually short-lived. In the last few years, two landmark studies have elucidated the potential clinical benefits of combining IFN- $\alpha$ and bevacizumab. Escudier et al. [14] conducted a randomized, double-blind, phase III trial comparing bevacizumab plus IFN- $\alpha$ to IFN- $\alpha$ monotherapy. Six hundred and forty-one previously untreated patients received bevacizumab $10 \mathrm{mg} / \mathrm{kg}$ every 2 weeks plus 9 million units of IFN- $\alpha$ subcutaneously 3 times a week or placebo plus IFN- $\alpha$ at an equivalent dosage. The median duration of progression-free survival (PFS) was substantially prolonged in the combination arm when compared to IFN- $\alpha$ alone (10.2 vs. 5.4 months) [14]. In a similar ran- domized phase III clinical trial, the Cancer and Leukemia Group B 90206 trial, 732 patients were randomly assigned to receive bevacizumab plus IFN- $\alpha$ or IFN- $\alpha$ monotherapy $[15,16]$. The primary endpoint was OS, and secondary endpoints were PFS and the objective response rate (ORR). Although the primary endpoint of OS did not reach predefined criteria for statistical significance, there were statistically significant increases in median PFS (8.5 months for the combination arm and 5.2 months for IFN$\alpha$ alone) and the ORR (25.5 vs. $13.1 \%)[15,16]$.

The combination of bevacizumab and sorafenib in the treatment of mRCC has been explored in two phase I trials. Azad et al. [17] randomized 39 patients with advanced solid malignancies into 2 cohorts that received bevacizumab $5 \mathrm{mg} / \mathrm{kg}$ every 2 weeks plus sorafenib $200 \mathrm{mg}$ twice daily (dose level $1 ; \mathrm{n}=33$ ) or bevacizumab $10 \mathrm{mg} /$ $\mathrm{kg}$ every 2 weeks with an equal dose of sorafenib (dose level $2 ; n=6$ ). Dose level 1 was found to be the maximum tolerated dose (MTD) since higher doses caused significant proteinuria and thrombocytopenia. Although this study did not include patients with RCC exclusively (only $8 \%$ of patients), all patients with RCC demonstrated either a partial response (PR) or stable disease (SD) [17]. In their phase I trial, Sosman et al. [18] went on to confirm the clinical activity of this combination in mRCC. Cohorts of at least 6 patients were enrolled to define the MTD and dose-limiting toxicity of bevacizumab (initial dose $5 \mathrm{mg} / \mathrm{kg}$ every 2 weeks) and sorafenib $200 \mathrm{mg}$ twice daily (with modification based on observed toxicities) on 28 -day cycles. The MTD was determined to be sorafenib $200 \mathrm{mg}$ p.o. daily and bevacizumab $5 \mathrm{mg} / \mathrm{kg}$ i.v. every 2 weeks. Twenty-one of 46 patients (46\%) had a PR according to the Response Evaluation Criteria In Solid Tumors. Additionally, 23 patients had SD. Median time to progression was 11.2 months. This landmark study opened the door for the ongoing BeST trial [18].

The mammalian target of rapamycin (mTOR) inhibitor everolimus has also been tested in combination with bevacizumab for the treatment of advanced clear cell RCC. A group of 50 untreated and 30 previously treated patients were given bevacizumab $10 \mathrm{mg} / \mathrm{kg}$ i.v. every 2 weeks and everolimus $10 \mathrm{mg}$ daily. The combination showed activity in both groups, with median PFS of 9.1 months for the treatment-naïve patients and 7.1 months for those who had previously received treatment [19]. Currently, there are several phase II and III trials testing the efficacy of this combination in mRCC.

However, as monumental as bevacizumab has been in the management of mRCC, to date the great majority of combination regimens including this agent have been un- 
successful in providing significant and durable clinical benefit. Two trials tested the efficacy and toxicity of bevacizumab and sunitinib in the treatment of mRCC. In a small case series reported by Medioni et al. [20], 7 patients who had progressed through sunitinib monotherapy were treated with bevacizumab $10 \mathrm{mg} / \mathrm{kg}$ every 2 weeks and sunitinib $25-50 \mathrm{mg}$ daily in a 4-week-on/2-week-off cycle. Two patients had a PR, 4 had SD and the remaining patient had disease progression. After a median followup of 17.2 months, median PFS was 8.5 months and OS was 15.1 months [20]. A slightly larger trial by Feldman et al. [21] randomized 3 cohorts of 3-6 patients $(n=25)$ to treatment with escalating doses of daily oral sunitinib in a 4-week-on/2-week-off cycle and fixed doses of bevacizumab $(10 \mathrm{mg} / \mathrm{kg})$ intravenously once every 2 weeks. Despite 1 patient achieving a complete response, 12 (48\%) a PR and 9 (36\%) SD, chronic therapy at the determined MTD resulted in intolerable toxicities, and further trials utilizing this combination were not pursued [21]. Any hope of this drug combination ever being used clinically in mRCC was shattered after Rini et al. [22] confirmed the unacceptably high incidence of thrombotic microangiopathy when this particular drug combination is used.

The combination of bevacizumab and erlotinib proved equally unfruitful. In a phase II trial, 63 patients were treated with $10 \mathrm{mg} / \mathrm{kg}$ bevacizumab every 2 weeks plus erlotinib $150 \mathrm{mg}$ daily [23]. After an 8-week evaluation period, patients who responded continued to receive the drug combination until disease progression. Twenty-five percent of patients had an objective response, $61 \%$ of patients had SD and only $14 \%$ of patients had disease progression after the initial evaluation period. Median PFS was 11 months, 1 -year PFS was $43 \%$ and OS at 18 months was $60 \%$. Despite these promising results, a subsequent study attempted to replicate this benefit by comparing bevacizumab and erlotinib versus bevacizumab monotherapy. One hundred and four patients received bevacizumab (10 mg/kg every 2 weeks) in combination with either erlotinib (150 mg daily) or placebo. Although the combination was well tolerated, it did not seem to provide additional clinical benefit when compared to bevacizumab alone (median PFS was 9.9 months for the combination and 8.5 months for bevacizumab monotherapy; hazard ratio 0.86) [24]. This combination was found to be equally ineffective in a phase I/II trial that used bevacizumab, erlotinib and imatinib [25]. In addition to displaying significant toxicity (most commonly grade $3 / 4$ diarrhea, rash and fatigue), the combination did not enhance clinical benefit when compared to the bevacizumab/erlotinib-only combination. Because of these nega- tive results, this combination has been abandoned for RCC altogether.

Similarly, bevacizumab has been combined with another mTOR inhibitor, temsirolimus. In an open-label, phase II study, Escudier et al. [26] administered bevacizumab and temsirolimus, sunitinib alone or bevacizumab and IFN- $\alpha$ to 171 randomly assigned patients. Recently, preliminary results from the TORAVA trial assessing the safety profile and efficacy of bevacizumab and temsirolimus indicated that this combination likely does not provide additive efficacy while demonstrating worse toxicity than expected [26]. Nevertheless, the final word will come once ongoing phase II and III trials are completed. Until then, bevacizumab will only continue to be used in combination with IFN- $\alpha$ for the treatment of good- or intermediate-risk clear cell renal carcinoma [27]. Further trials are pending that will potentially expand the use of bevacizumab for mRCC.

In the last few years, the TKI sunitinib has carved its way to become the standard choice as first-line monotherapy in clear cell carcinoma in good- to intermediaterisk RCC, in addition to being used as second-line therapy for clear cell RCC that has failed cytokine therapy or tumors of non-clear cell histology [27]. Sunitinib obtained US FDA approval as a first-line drug for the treatment of $m R C C$ after a randomized phase III study proved it was significantly superior to standard IFN- $\alpha$ therapy. Seven hundred and fifty treatment-naïve patients were randomly assigned to the sunitinib arm (50 mg orally, 4 -week-on/2-week-off dose schedule) or the IFN- $\alpha$ arm (9 million units subcutaneously, 3 times weekly) [28, 29]. Median OS was prolonged with sunitinib (26.4 vs. 21.8 months), and PFS with sunitinib was 11 months, while with IFN- $\alpha$ it was only 5 months. ORR was also increased about fourfold ( $47 \%$ for sunitinib vs. $12 \%$ for IFN- $\alpha$ ), effectively demonstrating sunitinib's advantage over IFN$\alpha$ in terms of OS, PFS and ORR. In 2009, Escudier et al. [30] reported that sunitinib at $37.5 \mathrm{mg} /$ day also provides significant gains in terms of median PFS and OS (8.2 and 19.8 months, respectively) in patients with cytokine-refractory mRCC, concluding that this dosing schedule offered an alternative to patients who develop significant adverse effects on standard dosing. However, this same group later amended their conclusion by stating that despite sharing similar ORR, OS and adverse event profiles, continuous dosing showed a trend toward inferior time to progression, making this schedule less desirable [31].

Sunitinib and everolimus were combined in a phase I trial reported by Kroog et al. [32]. Cohorts of 3-6 patients with mRCC were given sunitinib at $37.5 \mathrm{mg}$ daily or 50 
Table 1. Combination therapy trials for RCC

\begin{tabular}{|c|c|c|c|c|}
\hline Agents & Phase & $\begin{array}{l}\text { ORR, \%/PFS, months/ } \\
\text { OS, months }\end{array}$ & Comments & Reference \\
\hline \multirow[t]{2}{*}{ Bevacizumab + IFN } & III & $70 / 10.2 / \mathrm{NM}$ & AVOREN trial & Escudier et al. [14] \\
\hline & III & $13.1^{1 / 13} .2^{1} / \mathrm{NS}$ & CALGB 90206 trial & Rini et al. [16] \\
\hline \multirow[t]{2}{*}{ Bevacizumab + erlotinib } & II & $25 / 11 /-$ & & Hainsworth et al. [23] \\
\hline & II & $\mathrm{NS} / \mathrm{NS} / 20$ & no clinical benefit found & Bukowski et al. [24] \\
\hline $\begin{array}{l}\text { Bevacizumab + erlotinib + } \\
\text { imatinib }\end{array}$ & $\mathrm{I} / \mathrm{II}$ & $17 / 8.9 / 17.2$ & combination unacceptably toxic & Hainsworth et al. [25] \\
\hline Bevacizumab + everolimus & II & $\begin{array}{l}30(23)^{2} / 9.1(7.1)^{2} / 21.3 \\
(14.5)^{2}\end{array}$ & & Hainsworth et al. [19] \\
\hline Bevacizumab + temsirolimus & II & $25 / 43.2^{3} /-$ & TORAVA trial & Escudier et al. [26] \\
\hline \multirow[t]{2}{*}{ Bevacizumab + sorafenib } & I & efficacy not assessed & $\begin{array}{l}\text { included several solid tumor types, } \\
\mathrm{n}=3 \text { for RCC }\end{array}$ & Azad et al. [17] \\
\hline & $\mathrm{I}$ & $46 / 18 /-$ & $\mathrm{n}=47$ & Sosman et al. [18] \\
\hline \multirow[t]{2}{*}{ Bevacizumab + sunitinib } & - & $29 / 8.5 / 15.1$ & case series, $\mathrm{n}=7$ & Medioni et al. [20] \\
\hline & $\mathrm{I}$ & $52 / 11 /$ not reached & high discontinuation rate due to toxicity & Feldman et al. [21] \\
\hline Sunitinib + IFN & I & 12/11.9 (TTP)/- & $\begin{array}{l}\text { toxic as combination; } 4 \text {-week-on/2-week- } \\
\text { off schedule as effective as single agent }\end{array}$ & Motzer et al. [62] \\
\hline Sunitinib + temsirolimus & I & efficacy not assessed & $\mathrm{n}=3$; this combination not recommended & Patel et al. [33] \\
\hline Sunitinib + everolimus & I & efficacy not assessed & $\begin{array}{l}\mathrm{n}=19 ; \text { combination recommended for } \\
\text { phase II trials }\end{array}$ & Kroog et al. [32] \\
\hline \multirow[t]{2}{*}{ Sorafenib + IFN } & II & $19 / 7 / 17$ & $\begin{array}{l}\text { AE common to IFN limit this } \\
\text { combination }\end{array}$ & Ryan et al. [63] \\
\hline & II & $33 / 10 /-$ & $\begin{array}{l}\text { activity in treatment-naïve and } \\
\text { cytokine-treated patients }\end{array}$ & Gollob et al. [64] \\
\hline Sorafenib + everolimus & I & $25 /-1-$ & $\begin{array}{l}\text { best response in patients without prior } \\
\text { systemic treatment }\end{array}$ & Harzstark et al. [34] \\
\hline Sorafenib + IL-2 & II & $27.3 / \mathrm{NS} /-$ & ROSORC trial, open-label & Procopio et al. [65] \\
\hline
\end{tabular}

mg on a 4-week-on/2-week-off dosing schedule, and everolimus was administered either daily (2.5 or $5 \mathrm{mg}$ ) or weekly. Of the multiple cohorts, the combination of sunitinib $37.5 \mathrm{mg}$ daily and everolimus $20 \mathrm{mg}$ weekly was found to have the greatest efficacy with the lowest toxicity. However, efficacy was not one of the primary outcomes of this study, so further testing needs to be done before this combination can be deemed effective. The combination of sunitinib and temsirolimus has also been tested in the treatment of advanced RCC. In a dose-de- termining phase I study by Patel et al. [33], the combination of these drugs was administered to successive cohorts of 3-6 patients. Unfortunately, the study was stopped early due to dose-limiting toxicities. This combination is not currently in clinical use for RCC.

Harzstark et al. [34] conducted a phase I study of sorafenib and everolimus in mRCC. Twenty patients were divided into 3 cohorts with increasing medication dose levels (dose level 1 consisted of sorafenib $400 \mathrm{mg}$ twice a day and everolimus $2.5 \mathrm{mg}$ daily; dose level 2 was sorafenib 
Table 2. Grade $3 / 4$ side effects observed with combination therapy for RCC

\begin{tabular}{|c|c|c|}
\hline Agents (number of patients) & Side effect (percentage affected) & Reference \\
\hline Bevacizumab + IFN (362) & $\begin{array}{l}\text { hypertension (11) } \\
\text { asthenia (37) } \\
\text { anorexia (17) } \\
\text { proteinuria (15) }\end{array}$ & Rini et al. [16] \\
\hline Bevacizumab + everolimus (80) & $\begin{array}{l}\text { proteinuria (26) } \\
\text { stomatitis/mucositis (15) } \\
\text { asthenia (12) }\end{array}$ & $\begin{array}{l}\text { Hainsworth et al. } \\
{[19]}\end{array}$ \\
\hline Bevacizumab + temsirolimus (88) & $\begin{array}{l}\text { specific information on adverse events not reported; } \\
\text { however, grade } 3 \text { and } 4 \text { events were observed in } 34 \% \\
\text { of patients, and treatment in this cohort was stopped } \\
\text { prematurely for reasons other than progression in } \\
43 \%\end{array}$ & $\begin{array}{l}\text { Escudier et al. } \\
{[26]}\end{array}$ \\
\hline Bevacizumab + sorafenib (47) & $\begin{array}{l}\text { grade } 3 / 4 \text { toxicities included HFS and rash (with } \\
\text { bevacizumab } 5 \mathrm{mg} / \mathrm{kg} / \text { sorafenib } 200 \mathrm{mg} \text { twice daily } \\
\text { or greater); HTN (bevacizumab } 10 \mathrm{mg} / \mathrm{kg} \text { ) }\end{array}$ & $\begin{array}{l}\text { Sosman et al. } \\
{[18]}\end{array}$ \\
\hline Bevacizumab + sunitinib (26) & $\begin{array}{l}\text { fatigue, hemorrhage, hyponatremia, HFS }(10-20) \\
\text { thrombocytopenia, elevated lipase }(20-30) \\
\text { proteinuria, hypertension }(>30)\end{array}$ & $\begin{array}{l}\text { Feldman et al. } \\
{[21]}\end{array}$ \\
\hline Sunitinib + temsirolimus (3) & rash, cellulitis, thrombocytopenia, gout (all 33) & Patel et al. [33] \\
\hline Sunitinib + everolimus (19) & $\begin{array}{l}\text { not all data reported; however, } 5 / 11 \text { patients }(45 \%) \\
\text { suffered from mucositis and/or thrombocytopenia }\end{array}$ & Kroog et al. [32] \\
\hline Sorafenib + everolimus (20) & $\begin{array}{l}\text { diarrhea, asthenia, rash (10) } \\
\text { hypophosphatemia ( } 45)\end{array}$ & $\begin{array}{l}\text { Harzstark et al. } \\
{[34]}\end{array}$ \\
\hline
\end{tabular}

$400 \mathrm{mg}$ twice a day and everolimus $5 \mathrm{mg}$ daily, and dose level 3 was sorafenib $200 \mathrm{mg}$ twice a day and everolimus $10 \mathrm{mg}$ daily; cycle length for all levels was 4 weeks). Doselimiting toxicities were seen with both of the higher dose levels; therefore, dose level 2 was established as the MTD. Of the 14 patients randomized to the two higher dose levels, 8 (57\%) had SD and another 3 (21\%) had a PR. The authors concluded that the combination of sorafenib and everolimus was associated with acceptable toxicity with evidence of antitumor activity in RCC [34]. A few clinical trials are currently ongoing to determine the MTD, ORR and optimal dosing.

A comprehensive review of targeted therapies in advanced RCC would not be complete without mention of the VEGF and platelet-derived growth factor (PDGF) receptor inhibitors pazopanib, axitinib and tivozanib (AV951). Pazopanib is the latest targeted drug to be approved by the US FDA for the treatment of mRCC. In 2010, Hutson et al. [35] published the results of a phase II random- ized discontinuation trial that was later revised to an open-label study. It included a combination of 225 treatment-naïve patients (69\%) and patients who had received prior treatment with either a cytokine- or bevacizumabbased regimen (31\%). Patients received pazopanib $800 \mathrm{mg}$ daily. The ORR was $35 \%$ with a median duration of response of 68 weeks, and PFS was 52 weeks. Report of this study was closely followed by a phase III, randomized, placebo-controlled study that directly evaluated the efficacy and safety of pazopanib in treatment-naïve and prior cytokine-treated patients [12]. PFS was significantly prolonged in the pazopanib arm compared to the placebo arm ( 9.2 vs. 4.2 months), with the difference in PFS even more marked in the treatment-naïve patients (11.2 vs. 2.8 months). Axitinib, which has yet to be approved for the treatment of mRCC, showed promise as secondline therapy [34] and is actively being tested in phase III trials. The oral small-molecule TKI tivozanib also showed promising efficacy and acceptable safety and tolerability, 
Table 3. HIF inhibitors currently in clinical trials

\begin{tabular}{|c|c|c|}
\hline Agent & Target & Phase/status \\
\hline AFP464 & AhR & $\mathrm{I} / \mathrm{R}$ \\
\hline Carboxyamidotriazole & CCB in VEGF & I, II/ANR, C \\
\hline SU5416 & c-MET & I/ANR, C \\
\hline Alvocidib (flavopiridol) & $\begin{array}{l}\text { cyclin-dependent } \\
\text { kinase }\end{array}$ & $\mathrm{II} / \mathrm{C}$ \\
\hline Decitabine & $\begin{array}{l}\text { cytosine } \\
\text { nucleoside/DNMT }\end{array}$ & I/ANR, $C^{1}$ \\
\hline XL-647 & EGFR & $\mathrm{I} / \mathrm{C}$ \\
\hline Lonafarnib & $\begin{array}{l}\text { farnesyl-OH- } \\
\text { transferase }\end{array}$ & $\mathrm{II} / \mathrm{C}$ \\
\hline Valproic acid & HDAC & $\mathrm{I} / \mathrm{C}, \mathrm{R}^{1}$ \\
\hline MS-275 & HDAC & $\mathrm{I} / \mathrm{C}$ \\
\hline Belinostat & HDAC & $\mathrm{I} / \mathrm{C}, \mathrm{R}^{1}$ \\
\hline Tributyrin & HDAC & $\mathrm{I} / \mathrm{C}$ \\
\hline Trastuzumab & Her2/neu & $\mathrm{I} / \mathrm{C}^{1}$ \\
\hline Vandetanib & Her2/neu; EGFR & I, II/ANR, C, R \\
\hline Romidepsin (FK228) & HDAC & $\mathrm{II} / \mathrm{C}^{1}$ \\
\hline Vorinostat (SAHA) & HDAC & $\mathrm{I} / \mathrm{R}^{1}$ \\
\hline Panobinostat (LBH589) & HDAC & $\mathrm{I} / \mathrm{R}^{1}$ \\
\hline Tanespimycin & HSP & $\begin{array}{l}\text { I, II/ANR, C, EBI, } \\
\text { NYR }\end{array}$ \\
\hline Taxoprexin & microtubules & $\mathrm{II} / \mathrm{C}$ \\
\hline Docetaxel & microtubules & $\mathrm{II} / \mathrm{C}, \mathrm{T}^{1}$ \\
\hline Ixabepilone & microtubules & $\mathrm{I}, \mathrm{II} / \mathrm{C}^{1}$ \\
\hline Patupilone & microtubules & $\mathrm{II} / \mathrm{C}$ \\
\hline XL-765 & mTOR & $\mathrm{I} / \mathrm{R}$ \\
\hline Temsirolimus & mTOR & $\mathrm{I}, \mathrm{II} / \mathrm{NYR}, \mathrm{R}^{1}$ \\
\hline Everolimus & mTOR & I, II, III/R ${ }^{1}$ \\
\hline Pazopanib & multitarget TKI & $\mathrm{I} / \mathrm{R}^{1}$ \\
\hline Imatinib & PDGFR; cKIT & $\mathrm{I}, \mathrm{II} / \mathrm{ANR}, \mathrm{C}, \mathrm{T}^{1}$ \\
\hline Bortezomib & proteasome & I, II/ANR, $\mathrm{C}^{1}$ \\
\hline EZN-2968 & RNA & $\mathrm{I} / \mathrm{R}$ \\
\hline $\mathrm{PX}-12$ & thioredoxin & $\mathrm{I}, \mathrm{II} / \mathrm{C}$ \\
\hline Topotecan & topoisomerase & I, II \\
\hline Vatalanib & VEGF & I, II/ANR, C, R \\
\hline
\end{tabular}

$\mathrm{AhR}=$ Aryl hydrocarbon receptor; $\mathrm{CCB}=$ calcium channel blocker; $\mathrm{c}-\mathrm{MET}=\mathrm{c}$-MET proto-oncogene; DNMT = DNA methyltransferase; $\mathrm{HDAC}=$ histone deacetylase; $\mathrm{HSP}=$ heat shock protein; $\mathrm{ANR}=$ active not recruiting; $\mathrm{C}=$ completed; $\mathrm{EBI}=$ enrollment by invitation; NYR = not yet recruiting; $\mathrm{R}=$ recruiting; $\mathrm{T}=$ terminated.

${ }^{1}$ FDA approved.

as reported by Nosov et al. [36]. We are eagerly awaiting confirmation of these results and whether we will be adding these novel agents to our armamentarium against this difficult-to-treat malignancy.

Combination Antiangiogenic Therapy for Renal Cell Cancer
These findings on combination targeted therapy in advanced RCC are summarized in table 1.

\section{Toxicities Associated with Combination Therapy for RCC}

Despite being deemed 'targeted therapies', most if not all of the agents currently approved for the treatment of mRCC can have significant side effects. In contrast to systemic chemotherapy dose determination, which is largely based on MTD, targeted therapy dosing is based on safety assessments during phase I trials and is then modified in subsequent, more advanced-phase trials to provide maximal clinical activity [17]. Much of what we know about the safety profile and toxicities of these drugs has been elucidated from trials in which these agents were used as monotherapy. Hypertension, handfoot syndrome and hematologic abnormalities are known grade 3 and 4 side effects of the TKIs sunitinib and sorafenib. mTOR inhibitors temsirolimus and everolimus exhibit metabolic side effects like hypertriglyceridemia and hyperglycemia, in addition to asthenia, stomatitis and hematologic abnormalities. Bevacizumab has been associated with proteinuria, bleeding and hypertension as well as more serious complications including bowel perforation and thromboembolic events (when combined with other chemotherapeutic agents). It is therefore not surprising that when these drugs are used in combination, their toxicities can be compounded or enhanced (table 2).

\section{Rationale for Development of More Effective Antiangiogenic Therapy in RCC}

The traditional strategy to design combination therapy in clinical trials is to empirically combine agents with proven clinical efficacy. This strategy has been successful in deriving effective combination treatment. With the wealth of data available from molecular studies on tumor angiogenesis, we can now rationalize novel combinations which can readily be tested in preclinical models and then clinical trials.

Treatment with the currently available antiangiogenic agents, including sunitinib, sorafenib, pazopanib, axitinib or bevacizumab, would disrupt endothelial tubes and/or pericytes through the inhibition of VEGF/VEGF receptor (VEGFR) and PDGF/PDGF receptor (PDGFR) signaling pathways, respectively. Pericytes are vascular 


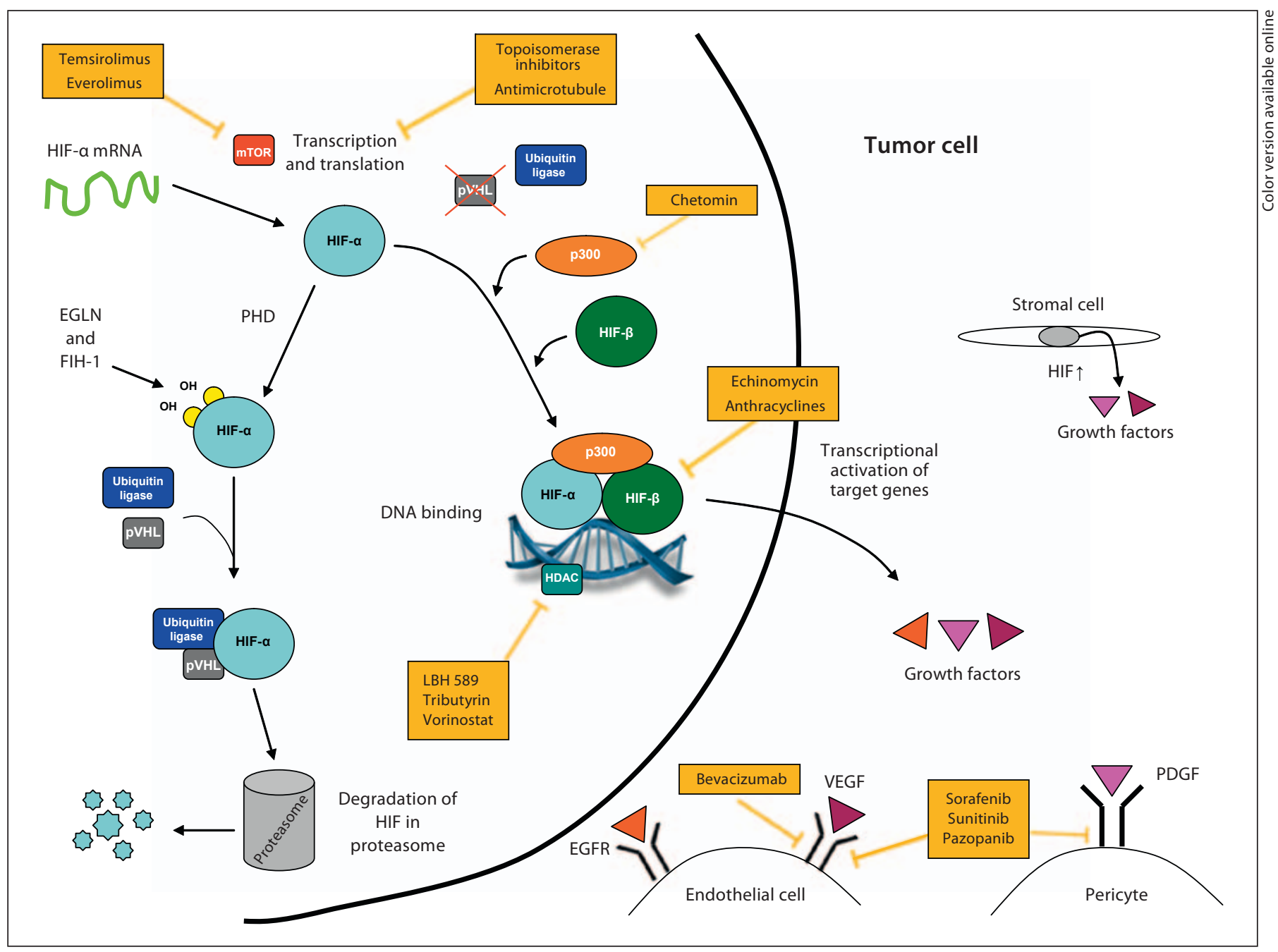

Fig. 1. Diagram depicting the tumor microenvironment and mechanism of known HIF inhibitors. HIF- $\alpha$ is overexpressed in cancer cells and stromal cells, thus promoting tumor angiogenesis by inducing the production of VEGF and other proangiogenic factors. HIF inhibitors work by disrupting HIF- $\alpha$ protein synthesis, stability or transcriptional activity. PHD = Prolyl hydroxylase; $\mathrm{pVHL}=$ von Hippel-Lindau protein; HDAC = histone deacetylase; p300 = transcriptional coactivator p300; EGFR = epidermal growth factor receptor; EGLN = EglNine gene; FIH-1 = factor inhibiting HIF-1.

smooth muscle cells that provide structural support and stabilization for sprouting endothelial tubes during vascular development. These support cells are responsible for sustaining tumor angiogenesis via paracrine production of VEGF. During tumor angiogenesis, cancer cells and endothelial cells synthesize and secrete PDGF- $\beta$, which acts in a paracrine fashion, stimulating pericytes to express VEGF. Due to their function in the propagation of tumor angiogenesis, pericytes serve as an important therapeutic target in the treatment of highly vascular cancers. Inhibiting both pericytes and endothelial cells would thus lead to a more significant antiangiogenic effect than inhibiting endothelial cells alone. As such, selection of clinically available agents with the most potent antiangiogenic effect would involve disrupting both the VEGF/VEGFR and PDGF/PDGFR pathways. This would include agents like sunitinib, pazopanib and axitinib.

Despite maximal inhibition of VEGF/VEGFR and PDGF/PDGFR pathways, resistance reliably develops due to a process known as 'reactive resistance' [37]. Effective antiangiogenic therapy works by creating a hypoxic condition devoid of nutrients for sustained cellular growth/ 
survival. However, intratumoral hypoxia leads to the induction of compensatory pathways that mediate resistance at the levels of the tumor blood vessels, microenvironment and tumor epithelial cells $[38,39]$. In preclinical models, hypoxia-inducible factor (HIF)- $1 \alpha$ and HIF- $2 \alpha$ have been shown to be major mediators of reactive resistance $[40,41]$. HIF- $1 \alpha$ and HIF-2 $\alpha$ induction would lead to the modulation of more than 200 genes important for inducing tumor angiogenesis, cancer cell growth/survival and energy metabolism, thus mediating resistance [42, 43]. In addition to mediating reactive resistance, HIF- $1 \alpha$ and HIF- $2 \alpha$ also mediate primary resistance due to their induction through dysregulated growth signaling by inflammatory mediators, growth factors and mutations in cancer genes [44-53]. As in many other solid tumors, overexpression of HIF- $1 \alpha$ and HIF- $2 \alpha$ has been shown to occur in RCC and may mediate resistance to therapy [54].

Thus, combining agents that inhibit HIF- $1 \alpha$ and HIF$2 \alpha$ with effective antiangiogenic agents, such as sunitinib, pazopanib or axitinib, would counteract reactive resistance and other driving forces of carcinogenesis. In a preclinical tumor model, we and others previously showed that combining antiangiogenic therapy with HIF inhibition is an effective therapeutic strategy $[41,55]$.

To date, high-throughput small-compound screens and mechanistic studies have identified several classes of anticancer agents that disrupt HIF- $1 \alpha$ function, including inhibition of the transcriptional activity, protein syn- thesis and stability of HIF-1 $\alpha$ [56-59]. Based on partial structural and functional similarities between HIF-1 $\alpha$ and HIF- $2 \alpha$, it is possible that many of the already identified HIF- $1 \alpha$ inhibitors would also inhibit HIF-2 $\alpha$. In addition, systematic efforts are currently ongoing to identify compounds that are effective at inhibiting both HIF$1 \alpha$ and HIF- $2 \alpha$ for cancer treatment $[60,61]$. Many of these HIF inhibitors are currently in clinical development, and two compounds (the mTOR inhibitors everolimus and temsirolimus) were recently approved for clinical use (table 3; fig. 1).

As we have discussed, everolimus and temsirolimus have been empirically combined with anti-VEGF agents, with significant toxicities (table 2). Further experimentation will be needed to determine the extent of target inhibition in these trials. For other HIF inhibitors, appropriate dosing and sequencing in combination with inhibitors of the VEGF/VEGFR and PDGFR/PDGFR pathways can be expeditiously tested in preclinical models and small phase I/II clinical trials. Selected promising combinations can then be tested for efficacy in large randomized trials.

\section{Disclosure Statement}

This study was funded by the National Comprehensive Cancer Network from general research support provided by Pfizer Inc. and NIH Grants K22CA111897 and R21CA115809.

\section{References}

1 American Cancer Society: Cancer Facts and Figures 2011. Atlanta, American Cancer Society, 2011.

2 Kumar V, Abbas AK, Fausto N: Robbins \& Cotran Pathologic Basis of Disease, ed 7. Elsevier, 2005.

-3 Carmeliet P, Jain RK: Angiogenesis in cancer and other diseases. Nature 2000;407:249257.

4 Folkman J: Angiogenesis in cancer, vascular, rheumatoid and other disease. Nat Med $1995 ; 1: 27-31$

5 Kerbel RS: Tumor angiogenesis: past, present and the near future. Carcinogenesis 2000;21: 505-515.

6 Gale NW, Thurston G, Davis S, Wiegand SJ, Holash J, Rudge JS, Yancopoulos GD: Complementary and coordinated roles of the VEGFs and angiopoietins during normal and pathologic vascular formation. Cold Spring Harb Symp Quant Biol 2002;67:267273.

Combination Antiangiogenic Therapy for Renal Cell Cancer
-7 Jain RK, Duda DG, Clark JW, Loeffler JS Lessons from phase III clinical trials on antiVEGF therapy for cancer. Nat Clin Pract Oncol 2006;3:24-40.

8 Chow LQ, Eckhardt SG: Sunitinib: from rational design to clinical efficacy. J Clin Oncol 2007;25:884-896.

-9 Hurwitz H, Fehrenbacher L, Novotny W, Cartwright T, Hainsworth J, Heim W, et al: Bevacizumab plus irinotecan, fluorouracil, and leucovorin for metastatic colorectal cancer. N Engl J Med 2004;350:2335-2342.

10 Bukowski RM: New antiangiogenic agents for renal cell carcinoma: bevacizumab. Curr Oncol Rep 2004;6:85-86.

11 Llovet JM, Ricci S, Mazzaferro V, Hilgard P, Gane E, Blanc JF, et al: Sorafenib in advanced hepatocellular carcinoma. N Engl J Med 2008;359:378-390.
12 Sternberg CN, Davis ID, Mardiak J, Szczylik C, Lee E, Wagstaff J, et al: Pazopanib in locally advanced or metastatic renal cell carcinoma: results of a randomized phase III trial. J Clin Oncol 2010;28:1061-1068.

13 Yang JC, Haworth L, Sherry RM, Hwu P, Schwartzentruber DJ, Topalian SL, et al: A randomized trial of bevacizumab, an antivascular endothelial growth factor antibody, for metastatic renal cancer. N Engl J Med 2003;349:427-434.

- 14 Escudier B, Pluzanska A, Koralewski P, Ravaud A, Bracarda S, Szczylik C, et al: Bevacizumab plus interferon alfa-2a for treatment of metastatic renal cell carcinoma: a randomised, double-blind phase III trial. Lancet 2007;370:2103-2111.

15 Rini BI, Halabi S, Rosenberg JE, Stadler WM, Vaena DA, Ou SS, et al: Bevacizumab plus interferon alfa compared with interferon alfa monotherapy in patients with metastatic renal cell carcinoma: CALGB 90206. J Clin Oncol 2008;26:5422-5428.

Renal Cell Cancer 
16 Rini BI, Halabi S, Rosenberg JE, Stadler WM, $>27$ Escudier B, Kataja V: Renal cell carcinoma: Vaena DA, Archer L, et al: Phase III trial of bevacizumab plus interferon alfa versus interferon alfa monotherapy in patients with metastatic renal cell carcinoma: final results of CALGB 90206. J Clin Oncol 2010;28:21372143.

- 17 Azad NS, Posadas EM, Kwitkowski VE, Steinberg SM, Jain L, Annunziata CM, et al: Combination targeted therapy with sorafenib and bevacizumab results in enhanced toxicity and antitumor activity. J Clin Oncol 2008;26:3709-3714.

18 Sosman JA, Flaherty KT, Atkins MB, McDermott DF, Rothenberg ML, Vermeulen WL, et al: Updated results of phase I trial of sorafenib (S) and bevacizumab (B) in patients with metastatic renal cell cancer (mRCC). J Clin Oncol 2008;26(May 20 suppl):abstract 5011

-19 Hainsworth JD, Spigel DR, Burris HA 3rd, Waterhouse D, Clark BL, Whorf R: Phase II trial of bevacizumab and everolimus in patients with advanced renal cell carcinoma. J Clin Oncol 2010;28:2131-2136.

-20 Medioni J, Banu E, Helley D, Scotte F, Fournier L, Mejean A, et al: Salvage therapy with bevacizumab-sunitinib combination after failure of sunitinib alone for metastatic renal cell carcinoma: a case series. Eur Urol 2009;56:207-211, quiz 211.

-21 Feldman DR, Baum MS, Ginsberg MS, Hassoun H, Flombaum CD, Velasco S, et al: Phase I trial of bevacizumab plus escalated doses of sunitinib in patients with metastatic renal cell carcinoma. J Clin Oncol 2009;27:1432-1439.

-22 Rini BI, Garcia JA, Cooney MM, Elson P, Tyler A, Beatty K, et al: Toxicity of sunitinib plus bevacizumab in renal cell carcinoma. J Clin Oncol 2010;28:e284-e285, author reply e286-e287.

-23 Hainsworth JD, Sosman JA, Spigel DR, Edwards DL, Baughman C, Greco A: Treatment of metastatic renal cell carcinoma with a combination of bevacizumab and erlotinib. J Clin Oncol 2005;23:7889-7896.

24 Bukowski RM, Kabbinavar FF, Figlin RA, Flaherty K, Srinivas S, Vaishampayan U, et al: Randomized phase II study of erlotinib combined with bevacizumab compared with bevacizumab alone in metastatic renal cell cancer. J Clin Oncol 2007;25:4536-4541.

-25 Hainsworth JD, Spigel DR, Sosman JA, Burris HA 3rd, Farley C, Cucullu H, et al: Treatment of advanced renal cell carcinoma with the combination bevacizumab/erlotinib/ imatinib: a phase I/II trial. Clin Genitourin Cancer 2007;5:427-432.

26 Escudier BJ, Negrier S, Gravis G, Chevreau C, Delva R, Bay J, et al: Can the combination of temsirolimus and bevacizumab improve the treatment of metastatic renal cell carcinoma (mRCC)? Results of the randomized TORAVA phase II trial (abstract 4516). J Clin Oncol 2010;28(suppl):15s. ESMO clinical recommendations for diagnosis, treatment and follow-up. Ann Oncol 2009;20(suppl 4):81-82.

28 Motzer RJ, Hutson TE, Tomczak P, Michaelson MD, Bukowski RM, Rixe O, et al: Sunitinib versus interferon alfa in metastatic renal-cell carcinoma. N Engl J Med 2007;356: 115-124.

29 Motzer RJ, Hutson TE, Tomczak P, Michaelson MD, Bukowski RM, Oudard S, et al: Overall survival and updated results for sunitinib compared with interferon alfa in patients with metastatic renal cell carcinoma. J Clin Oncol 2009;27:3584-3590.

30 Escudier B, Roigas J, Gillessen S, Harmenberg U, Srinivas S, Mulder SF, et al: Phase II study of sunitinib administered in a continuous once-daily dosing regimen in patients with cytokine-refractory metastatic renal cell carcinoma. J Clin Oncol 2009;27:40684075.

31 Motzer RJ, Hutson TE, Olsen MR, Hudes GR, Burke JM, Edenfield WJ, et al: Randomized phase II multicenter study of the efficacy and safety of sunitinib on the $4 / 2$ versus continuous dosing schedule as first-line therapy of metastatic renal cell carcinoma: Renal EFFECT Trial. J Clin Oncol 2011 29(suppl 7);abstract LBA308.

32 Kroog GS, Feldman DR, Kondagunta GV, Ginsberg MS, Fischer PM, Trinos MJ, et al: Phase I trial of RAD001 (everolimus) plus sunitinib in patients with metastatic renal cell carcinoma (abstract 5037^). J Clin Oncol 2009;27(suppl):15s.

33 Patel PH, Senico PL, Curiel RE, Motzer RJ: Phase I study combining treatment with temsirolimus and sunitinib malate in patients with advanced renal cell carcinoma. Clin Genitourin Cancer 2009;7:24-27.

34 Harzstark AL, Small EJ, Weinberg VK, Sun J, Ryan CJ, Lin AM, et al: A phase 1 study of everolimus and sorafenib for metastatic clear cell renal cell carcinoma. Cancer 2011;117: 4194-4200. PL, Rottey S, Hong BF, et al: Efficacy and safety of pazopanib in patients with metastatic renal cell carcinoma. J Clin Oncol 2010;28:475-480.

36 Nosov D, Bhargava P, Esteves WB, Strahs AL, Lipatov ON, Lyulko OO, et al: Final analysis of the phase II randomized discontinuation trial (RDT) of tivozanib (AV-951) versus placebo in patients with renal cell carcinoma (RCC). J Clin Oncol 2011;29 (suppl);abstract 4550 .

37 Blagosklonny MV: Antiangiogenic therapy and tumor progression. Cancer Cell 2004;5: 13-17.

38 Folkman J: A novel anti-vascular therapy for cancer. Cancer Biol Ther 2004;3:338-339.
35 Hutson TE, Davis ID, Machiels JP, De Souza
39 Casanovas O, Hicklin DJ, Bergers G, Hanahan D: Drug resistance by evasion of antiangiogenic targeting of VEGF signaling in latestage pancreatic islet tumors. Cancer Cell 2005;8:299-309.

40 Paez-Ribes M, Allen E, Hudock J, Takeda T, Okuyama H, Vinals F, et al: Antiangiogenic therapy elicits malignant progression of tumors to increased local invasion and distant metastasis. Cancer Cell 2009;15:220-231.

41 Burkitt K, Chun SY, Dang DT, Dang LH: Targeting both HIF-1 and HIF-2 in human colon cancer cells improves tumor response to sunitinib treatment. Mol Cancer Ther 2009; 8:1148-1156.

42 Semenza GL: Targeting HIF-1 for cancer therapy. Nat Rev Cancer 2003;3:721-732.

43 Chun SY, Johnson C, Washburn JG, CruzCorrea MR, Dang DT, Dang LH: Oncogenic KRAS modulates mitochondrial metabolism in human colon cancer cells by inducing HIF-1a and HIF-2a target genes. Mol Cancer 2010;9:293

44 Unruh A, Ressel A, Mohamed HG, Johnson RS, Nadrowitz R, Richter E, et al: The hypoxia-inducible factor-1 alpha is a negative factor for tumor therapy. Oncogene 2003;22: 3213-3220.

45 Bos R, Zhong H, Hanrahan CF, Mommers EC, Semenza GL, Pinedo HM, et al: Levels of hypoxia-inducible factor-1 alpha during breast carcinogenesis. J Natl Cancer Inst 2001;93:309-314.

46 Schindl M, Schoppmann SF, Samonigg H, Hausmaninger H, Kwasny W, Gnant M, et al: Overexpression of hypoxia-inducible factor lalpha is associated with an unfavorable prognosis in lymph node-positive breast cancer. Clin Cancer Res 2002;8:1831-1837.

47 Koukourakis MI, Giatromanolaki A, Sivridis E, Simopoulos C, Turley H, Talks K, et al: Hypoxia-inducible factor (HIF1A and HIF2A), angiogenesis, and chemoradiotherapy outcome of squamous cell head-andneck cancer. Int J Radiat Oncol Biol Phys 2002;53:1192-1202.

48 Aebersold DM, Burri P, Beer KT, Laissue J, Djonov V, Greiner RH, et al: Expression of hypoxia-inducible factor-1alpha: a novel predictive and prognostic parameter in the radiotherapy of oropharyngeal cancer. Cancer Res 2001;61:2911-2916.

49 Kurokawa T, Miyamoto M, Kato K, Cho Y, Kawarada Y, Hida Y, et al: Overexpression of hypoxia-inducible-factor 1alpha (HIF-1alpha) in oesophageal squamous cell carcinoma correlates with lymph node metastasis and pathologic stage. Br J Cancer 2003;89: 1042-1047.

50 Birner P, Schindl M, Obermair A, Plank C, Breitenecker G, Oberhuber G: Overexpression of hypoxia-inducible factor lalpha is a marker for an unfavorable prognosis in early-stage invasive cervical cancer. Cancer Res 2000;60:4693-4696. 
-51 Birner P, Schindl M, Obermair A, Breitenecker G, Oberhuber G: Expression of hypoxia-inducible factor lalpha in epithelial ovarian tumors: its impact on prognosis and on response to chemotherapy. Clin Cancer Res 2001;7:1661-1668.

- 52 Birner P, Gatterbauer B, Oberhuber G Schindl M, Rossler K, Prodinger A, et al: Expression of hypoxia-inducible factor-1 alpha in oligodendrogliomas: its impact on prognosis and on neoangiogenesis. Cancer 2001; 92:165-171.

53 Bachtiary B, Schindl M, Potter R, Dreier B, Knocke TH, Hainfellner JA, et al: Overexpression of hypoxia-inducible factor 1alpha indicates diminished response to radiotherapy and unfavorable prognosis in patients receiving radical radiotherapy for cervical cancer. Clin Cancer Res 2003;9:2234-2240.

-54 Rini BI, Atkins MB: Resistance to targeted therapy in renal-cell carcinoma. Lancet Oncol 2009;10:992-1000.
55 Rapisarda A, Hollingshead M, Uranchimeg B, Bonomi CA, Borgel SD, Carter JP, et al: Increased antitumor activity of bevacizumab in combination with hypoxia inducible factor-1 inhibition. Mol Cancer Ther 2009;8: 1867-1877.

56 Semenza GL: HIF-1 inhibitors for cancer therapy: from gene expression to drug discovery. Curr Pharm Des 2009;15:3839-3843.

57 Melillo G: Hypoxia-inducible factor 1 inhibitors. Methods Enzymol 2007;435:385-402.

58 Escuin D, Simons JW, Giannakakou P: Exploitation of the HIF axis for cancer therapy. Cancer Biol Ther 2004;3:608-611.

59 Giaccia A, Siim BG, Johnson RS: HIF-1 as a target for drug development. Nat Rev Drug Discov 2003;2:803-811.

60 Chun SY, Johnson C, Washburn JG, CruzCorrea MR, Dang DT, Dang LH: Oncogenic KRAS modulates mitochondrial metabolism in human colon cancer cells by inducing HIF- $1 \alpha$ and HIF-2 $\alpha$ target genes. Mol Cancer 2010;9:293.

-61 Scheuermann TH, Tomchick DR, Machius M, Guo Y, Bruick RK, Gardner KH: Artificial ligand binding within the HIF2alpha PAS-B domain of the HIF2 transcription factor. Proc Natl Acad Sci USA 2009;106:450455.
62 Motzer RJ, Hudes G, Wilding G, Schwartz LH, Hariharan S, Kempin S, et al: Phase I trial of sunitinib malate plus interferon-alpha for patients with metastatic renal cell carcinoma. Clin Genitourin Cancer 2009;7:2833.

63 Ryan CW, Goldman BH, Lara PN Jr, Mack PC, Beer TM, Tangen CM, et al: Sorafenib with interferon alfa-2b as first-line treatment of advanced renal carcinoma: a phase II study of the Southwest Oncology Group. J Clin Oncol 2007;25:3296-3301.

64 Gollob JA, Rathmell WK, Richmond TM, Marino CB, Miller EK, Grigson G, et al: Phase II trial of sorafenib plus interferon alfa-2b as first- or second-line therapy in patients with metastatic renal cell cancer. J Clin Oncol 2007;25:3288-3295.

65 Procopio G, Verzoni E, Bracarda S, Ricci S, Sacco C, Ridolfi L, et al: Sorafenib with interleukin-2 vs sorafenib alone in metastatic renal cell carcinoma: the ROSORC trial. Br J Cancer 2011;104:1256-1261. 